\title{
ASPEK BIOLOGI REPRODUKSI DAN POLA PERTUMBUHAN IKAN UCENG (Nemacheilus fasciatus) DALAM PEMELIHARAAN DI AKUARIUM
}

\author{
Vitas Atmadi Prakoso\#, Jojo Subagja, dan Anang Hari Kristanto \\ Balai Riset Perikanan Budidaya Air Tawar dan Penyuluhan Perikanan \\ (Naskah diterima: 25 Oktober 2017; Revisi final: 21November 2017; Disetujui publikasi: 21November 2017)
}

\begin{abstract}
ABSTRAK
Ikan uceng (Nemacheilus fasciatus) merupakan salah satu spesies ikan air tawar di Indonesia dengan nilai ekonomi cukup tinggi yang ketersediaannya masih mengandalkan penangkapan di alam, sehingga diperlukan upaya domestikasi untuk menjaga kelestariannya. Tujuan dari kegiatan ini adalah untuk mengamati biologi reproduksi dan pola pertumbuhan ikan uceng di lingkungan buatan (akuarium). Ikan uceng hasil tangkapan alam dari Sungai Progo, Temanggung, Jawa Tengah (panjang total 5,55 $\pm 0,53 \mathrm{~cm}$; bobot 2,49 $\pm 0,24 \mathrm{~g})$ diadaptasikan selama 12 bulan di akuarium $(40 \mathrm{~cm} \times 30 \mathrm{~cm} \times 30 \mathrm{~cm})$ dengan sistem air mengalir yang dilengkapi dengan aerator. Ikan uceng diberi Tubifex, hingga sampai akhirnya dapat beradaptasi dengan pakan komersial. Pakan komersial yang diberikan yaitu sebesar 3\%per hari dari biomassa tubuh dengan frekuensi dua kali sehari. Data biologi reproduksi diperoleh melalui koleksi data panjang total, bobot badan, bobot gonad, fekunditas, diameter telur, dan indeks kematangan gonad. Data pola pertumbuhan diperoleh dengan koleksi data panjang, bobot, dan sintasannya. Hasil penelitian menunjukkan bahwa induk betina yang gonadnya berkembang mempunyai warna bintik hitam yang jelas, sebaliknya induk jantan warna bintik hitam memudar. Indeks kematangan gonad (IKG) yang diamati pada ikan uceng setelah 12 bulan pemeliharaan yaitu berkisar antara 0,007-0,027 pada jantan dan 0,13-0,25 pada betina. Kisaran diameter telur yang diamati yaitu berkisar antara 0,61-0,68 mm, dengan fekunditas 680-4.198 butir. Sedangkan pola pertumbuhannya menunjukkan bahwa ikan uceng betina dan jantan memiliki pola pertumbuhan allometrik negatif ( $b=2,739$ pada betina; $b=2,895$ pada jantan). Nilai faktor kondisi Fulton (K) pada ikan uceng yang diamati yaitu 0,44-1,07 (rata-rata \pm SD: 0,70 $\pm 0,11$ ) pada betina dan 0,37-0,72 (rata-rata \pm SD: $0,60 \pm 0,06$ ) pada jantan. Dari pengamatan ini ditemukan bahwa proses perkembangan kematangan gonad ikan uceng di akuarium lebih lambat dibandingkan ikan uceng di habitat aslinya.
\end{abstract}

\section{KATA KUNCl: Nemacheilus fasciatus; domestikasi; biologi reproduksi; pertumbuhan}

ABSTRACT: Aspect of reproductive biology and growth pattern of barred loach (Nemacheilus fasciatus) reared in aquarium. By: Vitas Atmadi Prakoso, Jojo Subagja, and Anang Hari Kristanto

Barred loach (Nemacheilus fasciatus) is one of native fish species in Indonesia with high economic value, where their availability still depends on wild capture. Thus, domestication is needed to maintain its sustainability. The purpose of this study was to observe the reproductive biology and growth pattern of barred loach reared in aquarium (artificial environment). Fish were collected from Progo River, Temanggung, Central Java (total length of: $5.55 \pm 0.53 \mathrm{~cm}$; body weight: of $2.49 \pm 0.24 \mathrm{~g})$. The fish were reared for 12 months in aquarium $(40 \mathrm{~cm} \times 30 \mathrm{~cm} \times 30 \mathrm{~cm})$ with flowthrough system and equipped with aeration. The fish were fed with Tubifex until they accepted commercial feed. Then, the fish were fed twice a day at a ratio of $3 \%$ from the total fish biomass. The reproductive biology data were collected by measuring their total length, body weight, gonad weight, fecundity, egg diameter, and gonadosomatic index. Growth pattern were measured from length, weight, and survival. The results showed that matured female had shown black spot and male had inconsistent formation of black spots on their body. The gonadosomaticindexes ranged between $0.007-0.027$ for male and ranged between $0,13-0,25$ for female. The egg diameters ranged between 0.61 $0.68 \mathrm{~mm}$, with the fecundity of $680-4198$ eggs. The result of observation on growth pattern showed that female and male had negative allometric growth ( $b=2.739$ for female, $b=2.895$ for male). The value of Fulton condition factor

\footnotetext{
\# Korespondensi: Balai Riset Perikanan Budidaya Air Tawar dan Penyuluhan Perikanan. Jl. Sempur No. 1, Bogor 16154, Indonesia. Tel. + 622518313200

E-mail: vitas.atmadi@gmail.com
} 
$(K)$ in the observed fish was 0.44-1.07 (mean $\pm S D: 0.70 \pm 0.11$ ) on female and 0.37-0.72 (mean \pm SD: $0.60 \pm$ 0.06 ) on male. From this study, it was found that gonad maturity development of barred loach reared in aquarium was slower than those in their natural habitat.

\section{KEYWORDS: Nemacheilus fasciatus; domestication; reproductive biology; growth}

\section{PENDAHULUAN}

Ikan uceng (Nemacheilus fasciatus) merupakan jenis ikan lokal spesifik di Indonesia dan mempunyai nilai ekonomi tinggi, ikan ini biasanya dijual dalam bentuk olahan berupa goreng tepung dengan harga Rp200.000,00-Rp300.000,00 per kg; sehingga spesies ini potensial sebagai kandidat komoditas budidaya. Di Indonesia, populasinya tersebar di wilayah Jawa dan Sumatera (Prakoso et al., 2016). Ikan uceng, selain untuk dikonsumsi, juga diperjualbelikan sebagai komoditas ikan hias, karena tingginya penangkapan alam, maka dikhawatirkan dalam waktu tidak terlalu lama spesies ini akan menemui kepunahan. Upaya domestikasi untuk keperluan budidaya maupun konservasi agar spesies ini tetap lestari perlu dilakukan.

Sampai saat ini, belum banyak informasi yang mendukung domestikasi ikan uceng, khususnya untuk aspek budidayanya, sehingga permintaannya hanya dipenuhi dengan mengandalkan hasil tangkapan dari sungai. Penelitian tentang ikan uceng pernah dilakukan, namun masih berupa kajian informasi biologi ikan uceng di habitat aslinya (Risyanto et al., 2012).

Dalam mendukung domestikasi ikan uceng, salah satu aspek yang harus dipelajari dengan baik adalah daya adaptasi ikan di lingkungan ex situ terkait dengan biologi reproduksinya. Selain itu, tahapan domestikasi perlu didukung penelitian terkait dengan sifat biologi, genetik, penyakit maupun aspek sosial ekonomi (Maskur, 2002). Biswas (1993) menyatakan bahwa informasi mengenai bioreproduksi ikan, khususnya pada perubahan struktur gonad dapat digunakan untuk menentukan tingkat kematangan gonad. Pengamatan waktu matang gonad ikan uceng di lingkungan ex situ menjadi penting untuk dipelajari. Beberapa penelitian tentang biologi reproduksi ikan telah dilakukan pada berbagai spesies, seperti ikan nila (Peters, 1983), belanak (Sulistiono et al., 2001), gabus (Makmur \& Prasetyo, 2006), Iampam (Setiawan, 2007), mas (Kucharczyk et al., 2008), serta Rasbora tawarensis dan Poropuntius tawarensis (Muchlisin et al., 2010). Sedangkan penelitian tentang pola pertumbuhan juga telah dilakukan pada beberapa spesies ikan, di antaranya yaitu Mugil cephalus, Ambassis koopsii, dan Leiognathus fasciatus (Mulfizar et al., 2012), Mugil liza (Lemos et al., 2014), betutu (Fatah et al., 2016), dan lais (Jusmaldi, 2016). Informasi mengenai daya adaptasi ikan uceng yang berhubungan dengan biologi reproduksi dan pola pertumbuhannya masih belum banyak tersedia, lebih khusus lagi yaitu ikan uceng kandidat budidaya yang dipelihara pada lingkungan ex situ. Penelitian ini dilakukan untuk mengetahui aspek biologi reproduksi dan pola pertumbuhan ikan uceng yang diadaptasikan di akuarium guna mendukung proses domestikasi spesies untuk keperluan budidaya maupun konservasi.

\section{BAHAN DAN METODE}

Penelitian ini dilaksanakan di Balai Riset Perikanan Budidaya Air Tawar dan Penyuluhan Perikanan (BRPBATPP), Bogor. Koleksi ikan uceng diperoleh melalui hasil tangkapan alam dari Sungai Progo, Temanggung, Jawa Tengah (ukuran awal ikan dengan panjang total 5,55 $\pm 0,53 \mathrm{~cm}$ dan bobot 2,49 $\pm 0,24$ g). Ikan uceng hasil tangkapan alam sebanyak 100 ekor diangkut menuju ke Balai Riset Perikanan Budidaya Air Tawar dan Penyuluhan Perikanan, Bogor dan diadaptasikan selama 12 bulan di akuarium $(40 \mathrm{~cm} \times$ $30 \mathrm{~cm} \times 30 \mathrm{~cm}$ ) yang dilengkapi dengan substrat batu dan pasir agar menyerupai habitat aslinya dengan sistem air mengalir. Akuarium dilengkapi dengan aerator dan dikontrol suhunya pada kisaran $24^{\circ} \mathrm{C}-28^{\circ} \mathrm{C}$, selain itu selama 12 bulan tersebut, ikan uceng juga diadaptasikan dengan pemberian pakan alami berupa cacing Tubifex, hingga sampai akhirnya ikan uceng tersebut dapat beradaptasi dengan pemberian pakan komersial (pelet). Pakan yang digunakan dalam pemeliharaan ikan uceng adalah pelet terapung dengan kandungan protein $30 \%$ Jumlah pakan yang diberikan sebesar 3\% dari biomassa tubuh dan diberikan dua kali sehari.

Pengamatan terhadap ikan uceng yang dipelihara dalam akuarium dilakukan setelah pemeliharaan 12 bulan, karena ikan tersebut dibiarkan beradaptasi tanpa gangguan. Pengamatan jenis kelamin dilakukan secara visual terhadap semua ikan uceng yang dipelihara. Ikan uceng yang terpilih baik ikan betina dan jantan, diamati performa bagian perut dan genitalnya. Data lain yang dikoleksi yaitu panjang total, bobot badan ikan, dan bobot gonad setelah ikan dibedah. Pengukuran diameter telur dilakukan dengan bantuan mikroskop yang terhubung dengan kamera. Pengukuran diameter telur dilakukan sebanyak lima kali, kemudian dilakukan perhitungan rata-rata. Pengamatan gonad dilakukan 
dengan cara membedah ikan jantan dan betina masingmasing sebanyak 12 ekor. Fekunditas dan indeks kematangan gonad (IKG) juga dihitung. Fekunditas total ikan dihitung secara gravimetrik.

Pengukuran pola pertumbuhan dilakukan pada ikan uceng betina (panjang total 7,14 $\pm 0,62 \mathrm{~cm}$; bobot $3,50 \pm 0,71 \mathrm{~g} ; \mathrm{n}=55$ ekor) dan jantan (panjang total $6,95 \pm 0,68 \mathrm{~cm}$; bobot 2,06 $\pm 0,63 \mathrm{~g} ; \mathrm{n}=45$ ekor) yang dipelihara selama enam bulan di akuarium berukuran $30 \mathrm{~cm} \times 20 \mathrm{~cm} \times 20 \mathrm{~cm}$ yang diberi substrat batu dan pasir. Pakan komersial diberikan dengan frekuensi dua kali sehari sebanyak 3\%per hari dari total biomassa selama pemeliharaan. Data yang dikoleksi yaitu panjang, bobot, dan sintasannya. Parameter yang dianalisis yaitu hubungan panjang bobot dan faktor kondisinya. Pola pertumbuhan ikan dihitung dengan rumus $W=a^{b}$ (Jones et al., 1999; Ali et al., 2002; Fatih \& Cekic, 2002), di mana W = bobot basah ikan dan L adalah panjang total. Sementara itu, faktor kondisi untuk setiap ikan di hitung menggunakan rumus $\mathrm{K}=10^{5} \times \mathrm{W}(\mathrm{g}) / \mathrm{L}(\mathrm{mm})^{3}$ (Fulton, 1902; Weatherley \& Gill, 1987; Wootton, 1990). Data dianalisis menggunakan Microsoft Excel untuk analisis regresi dan penentuan koefisien korelasi.

\section{HASIL DAN BAHASAN}

Hasil pengamatan ikan uceng hasil adaptasi di akuarium setelah 12 bulan proses adaptasi menunjukkan bahwa induk ikan uceng yang mulai matang gonad secara visual dicirikan sebagai berikut: induk ikan uceng betina yang mulai matang gonad mempunyai warna bintik hitam lebih jelas, bentuk perut membulat pada bagian tengah dan mengecil ke arah genital, bentuk genital nya membulat, sedangkan induk jantan yang mulai matang gonad mempunyai warna bintik hitam yang sedikit memudar, bentuk perutnya sedikit membulat, serta genitalnya meruncing (Gambar 1).

Indeks kematangan gonad (IKG) ikan uceng jantan yang diamati melalui 12 ekor ikan sampel untuk pengamatan yaitu berada pada kisaran 0,007-0,027 (rata-rata \pm SD: 0,015 \pm 0,005), sedangkan IKG ikan uceng betina saat pengamatan lebih tinggi dibandingkan dengan IKG ikan uceng jantan, yaitu pada kisaran 0,13-0,25 (rata-rata \pm SD: 0,19 $\pm 0,04$ ) (Tabel 1). Saat pengamatan IKG, sudah mulai terbentuk bakal telur pada induk uceng betina, sedangkan pada jantan sedang mengalami tahap pematangan. Hasil pengamatan juga menunjukkan bahwa diameter telur ikan uceng betina yang diadaptasikan di akuarium memiliki kisaran 0,61-0,68 mm (rata-rata \pm SD: 0,65 $\pm 0,03 \mathrm{~mm}$ ), dengan kisaran fekunditas 680-4198 butir (rata-rata \pm SD: $1.573 \pm 1.065$ butir).
Indeks kematangan gonad sangat bervariasi pada beberapa jenis ikan yang telah diteliti (Coward \& Bromage, 1998; Prasetyo, 2006; Adisti, 2010). Faktor yang memengaruhi saat pertama kali ikan mencapai matang gonad yaitu spesies, umur, ukuran, dan sifatsifat fisiologi ikan tersebut. Setiap spesies ikan dan bahkan pada spesies yang sama tidak memiliki kesamaan awal matang gonadnya, hal ini dapat disebabkan perbedaan wilayah penyebaran dan banyaknya makanan (Effendie, 2002). Pada ikan uceng yang dipelihara di akuarium, faktor ketersediaan makanan yang cukup dimungkinkan merupakan penyebab perbedaan kecepatan matang gonad jika dibandingkan dengan ikan uceng di alam. Dari aspek fekunditas, nilai yang diperoleh hampir sama dengan kisaran fekunditas ikan uceng yang diamati dari alam. Risyanto et al. (2012) menemukan bahwa fekunditas ikan uceng di alam yaitu sebesar 1.665-7.567 butir. Variasi yang cukup besar dalam fekunditas antara ikan yang berukuran sama merupakan hal yang umum dan dapat disebabkan oleh faktor lingkungan, antara lain suhu, ketersediaan makanan, dan perbedaan genetik (Blaxter, 1969; Gibson \& Ezzi, 1978; Hoda \& Akhtar, 1985). Umumnya, fekunditas meningkat seiring dengan bertambahnya panjang atau bobot ikan, namun pada ikan kecil, nilai IKG sangat bervariasi.

Hasil pengamatan deskriptif gonad betina dan jantan ikan uceng secara visual disajikan pada Gambar 2. Berdasarkan hasil pengamatan makroskopik, terlihat bahwa ovarium ikan uceng berbentuk memanjang dan jumlahnya sepasang. Sementara itu, testis ikan uceng yang diamati berukuran lebih kecil dari gonad ikan uceng betina, berwarna putih, dan bentuknya belum memanjang dan bercabang seperti pada gonad ikan uceng betina.

Ikan uceng memiliki ovarium bertipe cystovarian, di mana perkembangan folikel ovarium berada di dalam tunika albuginea (kista), sementara itu, berdasarkan referensi dari penelitian sebelumnya yang meneliti ikan uceng hasil tangkapan alam, testis ikan uceng berbentuk memanjang dan jumlahnya sepasang. Testisnya bertipe tubular beranastomosa, yaitu testis yang tubulusnya tidak langsung berujung keluar, melainkan saling berhubungan dan membentuk jaringjaring (anastomosa) sebelum akhirnya menyatu dan bermuara keluar di bagian caudal (Rahmawati, 2014; Nurhidayat et al., 2017). Pada hasil penelitian ini, pengamatan gonad ikan uceng jantan yang diadaptasikan di akuarium menunjukkan bahwa perkembangan gonad ikan uceng jantan belum mencapai pada tahap matang gonad jika dibandingkan dengan penelitian sebelumnya pada ikan uceng jantan, karena bentuk testisnya belum memanjang dan belum 


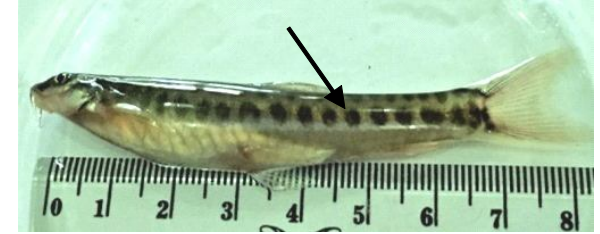

Warna bintik hitam padainduk ikan betina Black spots on female broodstock

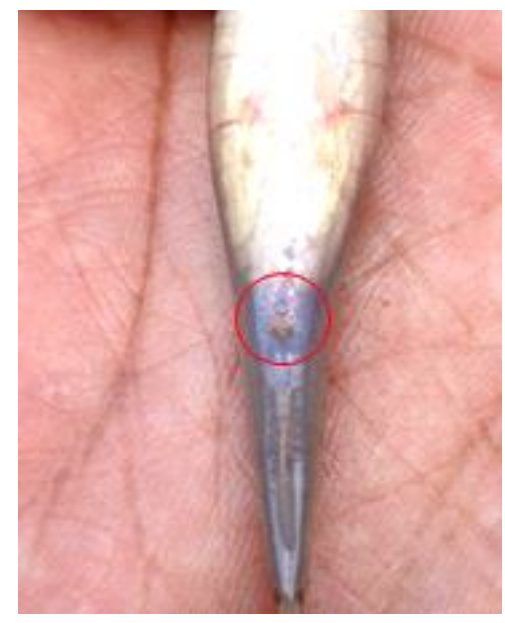

Perut induk ikan betina dan bentuk alat kelaminnya Stomach of femalebroodstock and female genital form

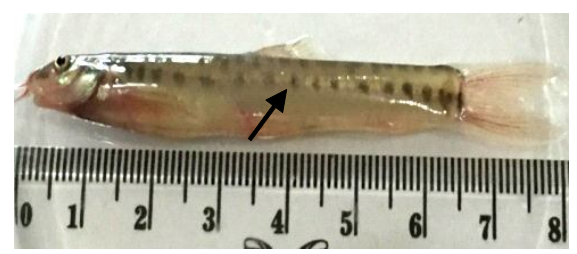

Warna bintik hitam pada induk ikan Jantan Black spots on male broodstock

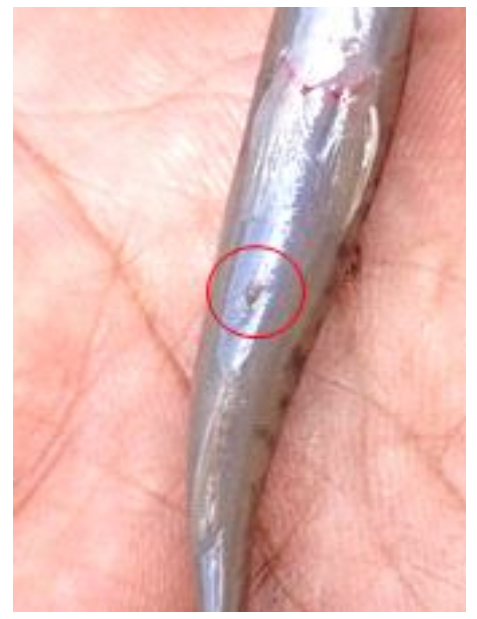

Perut induk ikan jantan dan bentuk alat kelaminnya Stomach of malebroodstock and male genital form

Gambar 1. Ciri-ciri visual induk ikan uceng yang matang gonad dan bentuk alat kelaminnya.

Figure 1. Visual characteristics on matured barred loach broodstock and its genital form.

membentuk sepasang. Pada pengamatan gonad ikan uceng betina menunjukkan perkembangan ke arah matang gonad dengan bentuk ovarium yang memanjang dan berjumlah sepasang.

Saat perkembangan kematangan gonad, semua proses metabolisme dalam tubuh ikan terkonsentrasi pada perkembangan gonad. Berkembangnya gonad pada setiap tahapannya menyebabkan ukuran dan bobot gonad mengalami peningkatan. Hal ini secara otomatis menyebabkan peningkatan nilai IKG sampai batas maksimum pada saat akan terjadi pemijahan (Effendie, 2002). Menurut Biswas (1993), perubahan struktur gonad secara visual dapat digunakan untuk menentukan tingkat kematangan gonad, yang akan berkorelasi dengan perkembangan telur dan sperma. Indeks kematangan gonad sering digunakan sebagai indikator status kematangan dalam banyak jenis ikan teleostei, selain itu indeks kematangan gonad dapat mencapai 20 dalam beberapa jenis salmonids (Tyler et al., 1990). Informasi mengenai indeks kematangan go nad pada ikan uceng ini belum banyak ditemui. Nilai ini lebih kecil jika dibandingkan dengan indeks kematangan gonad beberapa ikan yang masih satu genus dengan ikan uceng, seperti Nemacheilus moreh yang

Tabel 1. Indeks kematangan gonad induk ikan uceng (Nemacheilus fasciatus) hasil adaptasi di akuarium Table 1. Gonadosomatic index on barred loach (Nemacheilus fasciatus) broodstock acclimated in aquarium

\begin{tabular}{cccccc}
\hline $\begin{array}{c}\text { Jumlah dan jenis kelamin } \\
\text { Number of fish and sex }\end{array}$ & $\begin{array}{c}\text { Panjang standar } \\
\text { Standard length } \\
\mathbf{( c m})\end{array}$ & $\begin{array}{c}\text { Panjang total } \\
\text { Total length } \\
\mathbf{( c m})\end{array}$ & $\begin{array}{c}\text { Bobot badan } \\
\text { Body weight } \\
\mathbf{( g )}\end{array}$ & $\begin{array}{c}\text { Bobot gonad } \\
\text { Gonad weight } \\
\mathbf{( g )}\end{array}$ & $\begin{array}{c}\text { IKG } \\
\text { GSI }\end{array}$ \\
\hline $\begin{array}{c}12 \\
+ \\
12\end{array}$ & $5.97 \pm 0.77$ & $7.15 \pm 0.87$ & $2.60 \pm 1.00$ & $0.50 \pm 0.27$ & $0.19 \pm 0.04$ \\
0 & $6.19 \pm 0.57$ & $7.62 \pm 0.56$ & $2.42 \pm 0.61$ & $0.04 \pm 0.02$ & $0.0015 \pm 0.005$ \\
\hline
\end{tabular}




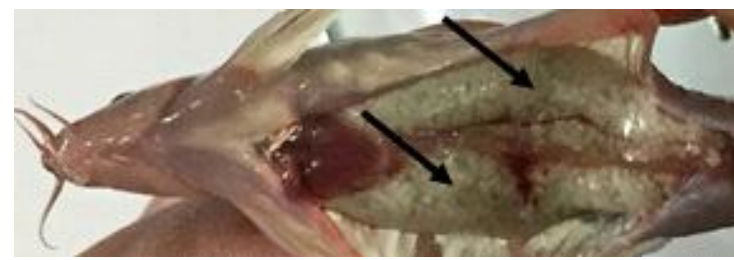

A

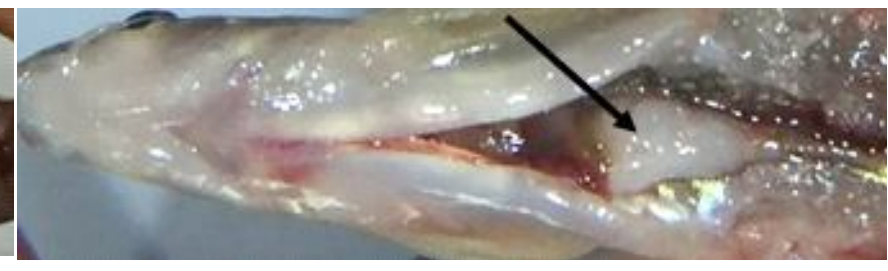

B

Gambar 2. Gonad ikan uceng (Nemacheilus fasciatus) (a. betina; b. jantan).

Figure 2. Gonad of barred loach (Nemacheilus fasciatus) (a. female; b. male).

memiliki indeks kematangan gonad pada kisaran $0,06-$ 0,31 pada jantan dan 0,16-10,38 pada betina (Kharat \& Khillare, 2013) dan Turcinoemacheilus hafezi pada kisaran $6,73 \pm 2,52$ pada jantan dan $14,50 \pm 2,78$ pada betina (Jamali et al., 2014). penelitian terdahulu pada spesies yang sama (Nemacheilus fasciatus) yang dilakukan oleh Risyanto et al. (2012) diperoleh nilai IKG antara 5,40-17,46. Nilai IKG pada ikan uceng betina yang diamati pada penelitian ini lebih rendah dari penelitian tersebut. Menurut Takashima \& Hibiya (1995), testis dalam keadaan tidak matang gonad berukuran lebih kecil, berwarna putih, dan berbentuk memanjang. Hal tersebut sesuai dengan ciri-ciri testis pada ikan uceng jantan yang diamati. Berdasarkan beberapa referensi tersebut, ikan uceng yang dipelihara di akuarium berada dalam keadaan belum matang gonad karena memiliki IKG yang lebih rendah dan ciricirinya sesuai dengan kategori ikan yang belum matang gonad. Hasil penelitian ikan uceng di alam, ukuran matang gonad untuk induk ikan uceng betina TKG-IV adalah 7-7,9 cm (Wardani, 2016). Hasil penelitian ini jika dibandingkan dengan ikan uceng yang dipelihara di akuarium sudah masuk dalam kriteria ukuran yang matang gonad, namun pada penelitian ini ditemukan bahwa ikan uceng belum matang gonad dan TKG tertinggi yang ditemukan yaitu III. Berdasarkan hasil temuan ini, dapat diketahui bahwa pada pemeliharaan di akuarium ikan uceng lebih lambat matang gonad dibandingkan dengan ikan uceng di alam.

Hasil pengamatan pola pertumbuhan menunjukkan bahwa ikan uceng betina memiliki pertumbuhan yang bersifat allometrik negatif $(b=2,739)$, dan ikan uceng jantan bersifat allometrik negatif $(b=2,895)$. Nilai koefisien determinasi $\left(R^{2}\right)$ pada ikan uceng betina yaitu 0,727 ; sedangkan pada ikan uceng jantan sebesar 0,873 (Gambar 3). Sintasan untuk ikan uceng betina yaitu 92,73 \% sedangkan ikan uceng jantan sebesar 95,56\%

Nilai koefisien korelasi ( $r$ ) sebesar 0,853 pada ikan uceng betina dan 0,934 pada ikan uceng jantan. Nilai koefisien korelasi ini menunjukkan adanya hubungan yang erat antara pertambahan bobot dengan pertambahan panjang. Nilai koefisien determinasi sebesar 0,727 dan 0,873 menyatakan bahwa 72,7\%dan $87,3 \%$ dari total varian pertambahan bobot dapat dijelaskan oleh grafik hubungan panjang-bobot.

Habitat, aktivitas ikan, kebiasaan makanan, dan tingkat pertumbuhan musiman merupakan beberapa faktor yang memengaruhi pertumbuhan ikan (Mizuno \& Furtado, 1982; Lowe-McConnell, 1987). Pada penelitian ini, nilai " $b$ " pada ikan uceng betina dan jantan menunjukkan nilai yang lebih rendah dari tiga, di mana pertumbuhan panjang lebih dominan dibandingkan bobot, sehingga ikan terlihat lebih ramping (Jobling, 2002). Nilai b yang lebih rendah dari tiga pada ikan uceng ini juga berhubungan dengan aktivitas ikan ini. Alokasi energi yang dikeluarkan untuk bergerak dan tumbuh cukup besar karena sifat ikan ini yang merupakan perenang aktif. Hal ini sesuai dengan pendapat dari Nikolsky (1963), Shukor et al. (2008), dan Muchlisin et al. (2010) yang menyebutkan bahwa ikan tipe perenang aktif umumnya memiliki nilai $b$ yang lebih rendah dibandingkan dengan ikan perenang pasif karena aktivitas renang yang lebih banyak membutuhkan energi yang lebih besar dibandingkan ikan yang bertipe perenang pasif.

Hasil pengamatan menunjukkan bahwa ikan uceng betina memiliki faktor kondisi Fulton (K) berkisar 0,44 sampai 1,07 (rata-rata $\pm \mathrm{SD}: 0,70 \pm 0,11$ ), sedangkan ikan uceng jantan berkisar antara 0,37 sampai 0,72 (rata-rata \pm SD: 0,60 $\pm 0,06$ ). Nilai faktor kondisi tersebut menunjukkan bahwa ikan uceng yang dipelihara di akuarium berada dalam kondisi yang baik.

Hubungan panjang bobot dan faktor kondisi merupakan parameter yang dapat menggambarkan tingkat pertumbuhan dan kondisi ikan tertentu (Muchlisin et al., 2010). Menurut Richter (2007), panjang bobot dan faktor kondisi juga dapat memberikan gambaran tentang kesehatan ikan dan lingkungannya. Hasil pengamatan pada ikan uceng yang dipelihara di akuarium ini mengindikasikan bahwa kondisi lingkungan pemeliharaan baik bagi 

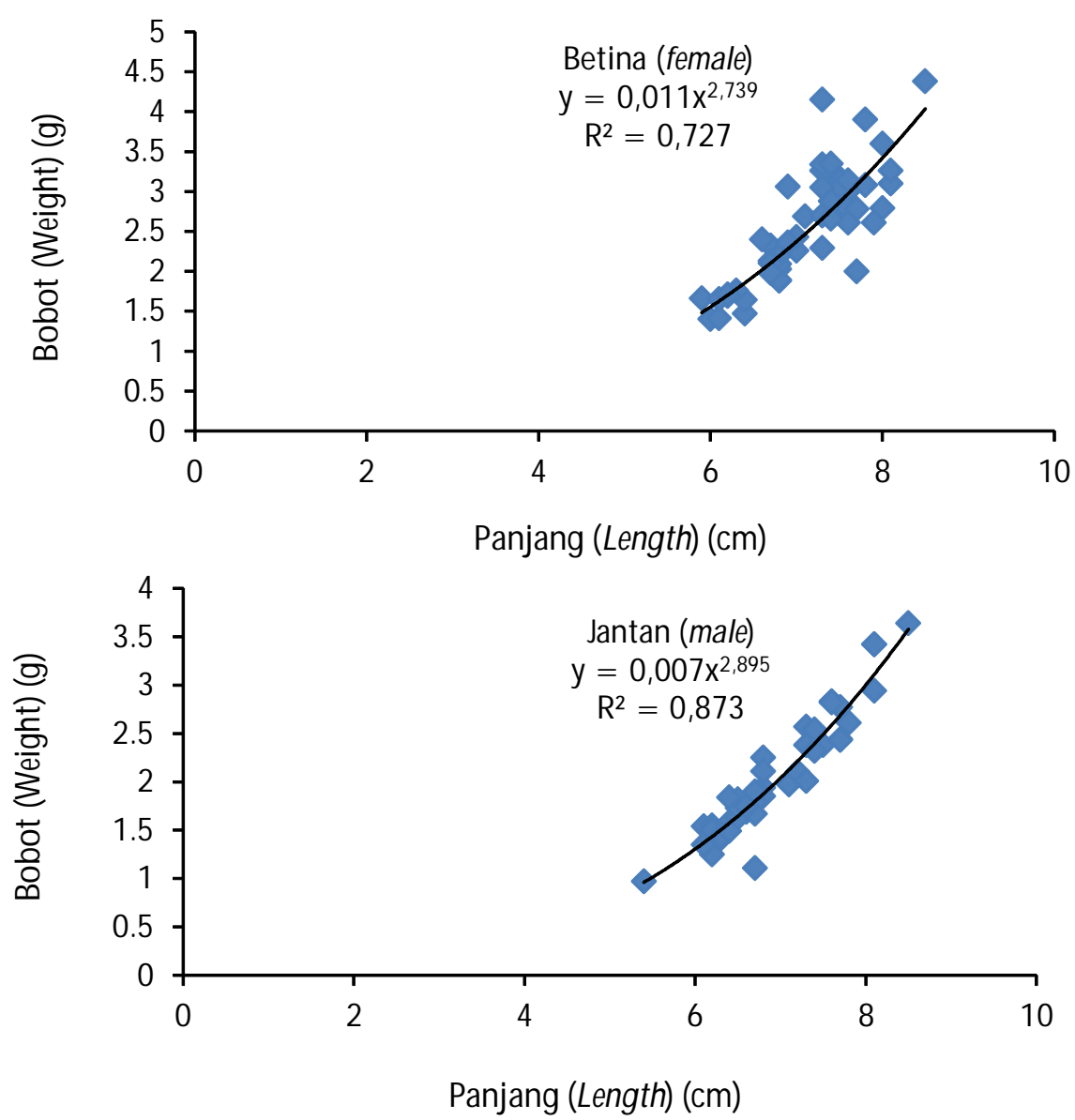

Gambar 3. Hubungan panjang-bobot ikan uceng (Nemacheilus fasciatus) yang dipelihara di akuarium.

Figure 3. Length-weight relationship of barred loach (Nemacheilus fasciatus) reared in aquarium.

pertumbuhan. Effendie (2002) menyatakan bahwa variasi nilai faktor kondisi dipengaruhi oleh makanan, umur, jenis kelamin, dan tingkat kematangan gonad. Pada penelitian ini tidak terlihat adanya perbedaan faktor kondisi antara kelompok ikan uceng betina dan jantan. Hal tersebut juga disebabkan karena ikan tersebut memiliki kisaran umur yang hampir sama, dipelihara pada kondisi lingkungan yang relatif sama dan terkontrol, serta diberi jenis pakan yang sama.

\section{KESIMPULAN}

Induk ikan uceng yang diadaptasikan di akuarium dapat berkembang gonadnya. Namun, kematangan gonadnya lebih lambat dibandingkan ikan uceng di habitat aslinya. Diperlukan penelitian lebih lanjut untuk mengkaji mengenai pemijahan buatan ikan uceng hasil adaptasi di akuarium melalui penyuntikan hormon.

\section{UCAPAN TERIMA KASIH}

Penulis berterima kasih kepada Bambang Priadi, Sofyan, dan Sri Sundari yang telah berkontribusi dalam penelitian ini.

\section{DAFTAR ACUAN}

Adisti. (2010). Kajian biologi reproduksi ikan tembang (Sardinella maderensis Lowe, 1838) di Perairan Teluk Jakarta yang didaratkan di PPI M uara Angke, Jakarta Utara. Skripsi. Institut Pertanian Bogor. Bogor, 64 $\mathrm{hlm}$.

Ali, M., Salam, A., Iqbal, F., \& Ali Khan, B. (2002). Growth performance of Channa punctata from two ecological regimes of Punjab, Pakistan. Pakistan Journal of Biological Sciences, 5, 1123-1125.

Biswas, S.P. (1993). Manual of methods in fish biology. New Delhi: South Asian Publishers Pvt Ltd. 
Blaxter, J.H.S. (1969). Development: Eggs and larvae. In Fish Physiology. Hoar, W.S. \& Randall, J.J. (Eds.). New York and London: Academic Press, p. 177-184.

Bromage, N.R. \& Cumaranatunga, P.R.T. (1988). Egg production in the rainbow trout. In Recent Advances in Aquaculture. Muir, J.F. \& Roberts, R. J. (Eds.). London: Croom Helm, p. 65-138.

Coward, K. \& Bromage, N.R. (1998). Histological classification of oocyte growth and the dynamics of ovarian recrudescence in Tilapia zillii. Journal of Fish Biology, 53, 285-302.

Effendie, M.I. (2002). Biologi perikanan. Yogyakarta: Yayasan Pustaka Nusantara, $112 \mathrm{hlm}$.

Fatah, K. \& Adjie, S. (2016). Biologi reproduksi ikan betutu (Oxyeleotris marmorata) di Waduk Kedungombo Provinsi Jawa Tengah. BAWAL, 5(2), 89-96.

Fatih, M. \& Cekic, M. (2002). Weight-length relationships for selected fish species of the small-scale fisheries off the South Coast of Skenderun Bay. The Turkish Journal of Veterinary and Animal Sciences, 26, 1181-1183.

Fulton, T. (1902). Rate of growth of seas fishes. Science Investigation of Fisheries Division Scotland Report, $20 \mathrm{pp}$.

Gibson, R.N. \& Ezzi, I.A. (1978). The biology of a Scottish population of fries go by Lesuerigobius friesil. Journal of Fish Biology, 12, 371-389.

Hoda, M.S. \& Akhtar, Y. (1985). Maturation and fecundity of mudskipper Boleopthalmius dentatus in the northern Arabian Sea. Indian Journal of Fisheries, 32(1), 64-73.

Jamali, H., Patimar, R., Farhadi, M., Golzarianpour, K., \& Daraei, V. (2014). Some aspects of the life history of Turcinoemacheilus hafezi (Teleostei: Nemacheilidae) from Beshar River, Southwestern Iran. Iranian Journal of Ichthyology, 1(1), 32-38.

Jobling, M. (2002). Environmental factors and rates of development and growth. In Handbook of Fish Biology and Fisheries, 1. Hart, P.J.B. \& Reynolds, J.D. (Eds.). Blackwell Publishing, p. 107-109.

Jones, R.E., Petrell, R.J., \& Pauly, D. (1999). Using modified length-weight relationships to assess the condition of fish. Aquacultural Engineering, 20, 261276.

Jusmaldi. (2016). Karakteristik biometrik dan genetik spesies ikan lais (Siluridae) dan biologi reproduksi Ompok miostoma (Vaillant, 1902) di Sungai Mahakam Kalimantan Timur. Disertasi. Institut Pertanian Bogor. Bogor, $117 \mathrm{hlm}$.
Kharat, S.S. \& Khillare, Y.K. (2013). Gonadosomatic index, ova diameter and fecundity of fresh water hill stream Teleost Nemacheilus moreh (Sykes). International Journal of Bioassays, 2(8), 992-995.

Kucharczyk, D., Targoñska, K., Hliwa, P., Gomuka, P., Kwiatkowski, M., Krejszeff, S., \& Perkowski, J. (2008). Reproductive parameters of common carp (Cyprinus carpio L) spawners during natural season and out-of-season spawning. Reproductive Biology, 8(3), 285-289.

Lemos, V.M., Varela, Jr.A.S., Schwingel, P.R., Muelbert, J.H., \& Vieira, J.P. (2014). Migration and reproductive biology of Mugil liza (Teleostei: Mugilidae) in South Brazil. Journal of Fish Biology, 85, 671687.

Lowe-McConnell, R.H. (1987). Ecological studies in tropical fish communities. London: Cambridge University Press, p. 159-173.

Makmur, S. \& Prasetyo, D. (2006). Kebiasaan makan, tingkat kematangan gonad dan fekunditas ikan haruan (Channa striata Bloch) di suaka perikanan Sungai Sambujur DAS Barito Kalimantan Selatan. Jurnal IImu-ilmu Perairan dan Perikanan Indonesia, 13(1), 27-31.

Maskur. (2002). Program pelestarian plasma nutfah ikan-ikan perairan umum. Jurnal Akuakultur Indonesia, 1(3), 139-144.

Mizuno, N. \& Furtado, J.I. (1982). Ecological notes on fishes. In Tasek Bera. The ecology of a freshwater swamp. Furtado, J.I. \& Mori, S. (Eds.). Monographiae Biologicae, no. 47. The Hague: Dr. W. Junk, p. 321-354.

Muchlisin, Z.A., Musman, M., \& Siti-Azizah, M.N. (2010). Length-weight relationships and condition factors of two threatened fishes, Rasbora tawarensis and Poropuntius tawarensis, endemic to Lake Laut Tawar, Aceh Province, Indonesia. Journal of Applied Ichthyology, 26, 949-953.

Mulfizar, Z.A., Muchlisin \& Dewiyanti, I. (2012). Hubungan panjang berat dan faktor kondisi tiga jenis ikan yang tertangkap di perairan Kuala Gigieng, Aceh Besar, Provinsi Aceh. Depik, 1, 1-9.

Nikolsky, G.V. (1963). The ecology of fishes. Translated by L. Birkett. Academic Press, 352 pp.

Nurhidayat, L., Arviani, F.N. \& Retnoaji, B. (2017). Indeks gonadosomatik dan struktur histologis gonad ikan uceng (Nemacheilus fasciatus, Valenciennes in Cuvier and Valenciennes, 1846). Biosfera, 34(2), 67-74.

Peters, H.M. (1983). Fecundity, egg weight and oocyte development in tilapias (Cichlidae, Teleostei). 
ICLARM Translations 2, International Center for Living Aquatic Resources Management, Manila, Philippines, 28 pp.

Prakoso, V.A., Ath-thar, M.H.F., Subagja, J., \& Kristanto, A.H. (2016). Pertumbuhan ikan uceng (Nemacheilus fasciatus) dengan padat tebar berbeda dalam lingkungan ex situ. Jurnal Riset Akuakultur, 11(4), 355-362.

Prasetyo, B. (2006). Studi biologi reproduksi ikan tembang (Sardinella fimbriata) di Perairan Ujung Pangkah, Kabupaten Gresik, Jawa Timur. Skripsi. Institut Pertanian Bogor. Bogor, $59 \mathrm{hlm}$.

Rahmawati, S. (2014). Indeks gonadosomatik dan struktur histologis gonad ikan wader pari (Rasbora lateristriata Bleeker, 1854) pada tahap perkembangan pra dewasa dan dewasa. Skripsi. Fakultas Biologi Universitas Gadjah Mada. Yogyakarta, hlm. 21-25.

Richter, T.J. (2007). Development and evaluation of standard weight equations for bridgelip sucker and largescale sucker. North American Journal of Fisheries M anagement, 27, 936-939.

Risyanto, S., Ardli, E.R., \& Sulistiyo, I. (2012). Biologi ikan uceng (Nemacheilus fasciatus C.V.) di Sungai Banjaran Kabupaten Banyumas. Biosfera, 29(1), 51-58.

Setiawan, B. (2007). Biologi reproduksi dan kebiasaan makan ikan lampam (Barbonymus schwanenfeldii) di Sungai M usi, Sumatera Selatan. Skripsi. Institut Pertanian Bogor. Bogor, $117 \mathrm{hlm}$.
Shukor, M.Y., Samat, A., Ahmad, A.K., \& Ruziaton, J. (2008). Comparative analysis of length-weight relationship of Rasbora sumatrana in relation to the physicochemical characteristic in different geographical areas in peninsular Malaysia. Malaysian Applied Biology, 37, 21-29.

Sulistiono, Jannah, M.R., \& Ernawati, Y. (2001). Reproduksi ikan belanak (Mugil dussumieri) di perairan Ujung Pangkah, Jawa Timur. Jurnal Iktiologi Indonesia, 1(2), 31-37.

Takashima, F. \& Hibiya, T. (1995). Gonad. In An atlas of fish histology normal and pathological features. Takashima, F. \& Hibiya, T. (Eds.). Tokyo: Kodansu, Ltd., p. 128-153.

Tyler, C., Sumpter, J.P., \& Witthames, P.R. (1990). The dynamics of oocyte growth during vitellogenesis in the rainbow trout, Salmo gairdneri. Biology of Reproduction, 43, 202-209.

Wardani, R.R. (2016). Tingkat kedewasaan ikan uceng (Nemacheilus fasciatus) betina berdasarkan aspek reproduksi dan level hormonal di Sungai Lekso, Desa Babadan Kecamatan Wlingi Kabupaten Blitar. Tesis. Universitas Brawijaya.

Weatherley, A.H. \& Gill, H.S. (1987). The biology of fish growth. London: Academic Press, $443 \mathrm{pp}$.

Wootton, R.J. (1990). Ecology of teleost fishes. 1st ed. London: Chapman and Hall, p. 43-169. 